\title{
The Tunisian Artemisia Essential Oil for Reducing Contamination of Stored Cereals by Tribolium castaneum
}

\author{
Ikbal Chaieb ${ }^{1,2}$, Amel Ben \\ Hamouda ${ }^{2 *}$, Wafa Tayeb3 \\ Khaoula Zarrad², Thameur \\ Bouslema ${ }^{2}$ and Asma Laarif ${ }^{2}$
}

'Laboratory of Plant Protection, University of Carthage, National Agricultural Research Institute of Tunisia, Hédi Karray Street, TN-2049 Ariana, Tunis, Tunisia ${ }^{2}$ University of Sousse, Regional Centre of Research on Horticulture and Organic Agriculture, 57, Chott Mariem, TN-4042 Sousse, Tunisia ${ }^{3}$ Biochemistry Laboratory, Nutrition-Functional Foods and Vascular Health, University of Monastir, Faculty of Medicine, Avicenne Street, TN-5019 Monastir, Tunisia

Received: 16 July 2017 Accepted: 22 November 2017
*Corresponding author:

E-mail: ben.hamouda@yahoo.fr

ORCID IDs: 0000-0002-7556-7197 (Chaieb), 0000-0003-3985-0734 (Ben Hamouda), 0000-0003-0610-8277 (Tayeb), 0000-0002-2739-6303 (Zarrad), 0000-0002-7429-3198 (Bouslema), 0000-0003-2792-9904 (Laarif)

\section{SUMMARY}

Essential oils of three species of Artemisia genus (A. absinthium L., A. campestris L. and A. herba-alba (Asso)) were analyzed by gas chromatography-mass spectrometry (GC-MS) and their potential insecticidal and repellent activities against the stored grain insect Tribolium castaneum (Herbst) was investigated. Fumigant and repellent activity bioassays were investigated in vitro. Chemical characterisation of essential oils showed that the bicyclic monoterpenes were predominant in all Artemisia essential oils, A. absinthium essential oil having the highest content of bicyclic monoterpenes, bicycloheptanes, naphthalenes and cycloalkenes. A. campestris had the highest content of sesquiterpenoids and acyclic monoterpenoids. A. herba-alba was characterised by the highest amounts of menthane monoterpenoids, oxanes, cumenes, oxolanes, ketones, benzenoids and monocyclic monoterpenes. Fumigant bioassay demonstrated that the three types of oil applied separately caused significant insect mortality. The lowest median lethal dose, $\mathrm{LC}_{50}=142.8 \mu \mathrm{L} / \mathrm{L}$, was observed with $A$. herba-alba. In repellency test, essential oil of $A$. absinthium was more potent with more rapid action than all other species. The mixture of Artemisia sp. essential oils showed an antagonistic effect in all the tested combinations. This study highlighted an important potential of Artemisia sp. especially A. herba-alba and A. absinthium in the control of the pests of stored products.

Key words: Artemisia sp., essential oil, chemical composition, insecticidal activity, repellency

\section{INTRODUCTION}

Insects are considered as the major source of damage in stored grains. They often cause significant economic damage of 5 to $10 \%$ in the temperate zone and 20 to $30 \%$ in the tropical one (1). In modern storage technologies, controlling insects is managed by chemical insecticides, including both fumigants and contact insecticides, which present serious threat to human health and environment, leave residues and enhance insect resistance. Besides, the high cost of the treatment requires new alternatives for insect control (2). Fumigation is still among the most effective and widespread techniques for the control of stored product. Methyl bromide and phosphine are the two most common and widely used fumigants $(3,4)$. In addition, carbon dioxide and sulfuryl fluoride are also used for fumigation of stored grain as alternatives to phosphine (5). However, the current fumigants are a cause for some concerns since methyl bromide has been phased out in many countries including Tunisia because it has been found to cause stratospheric ozone layer depletion (4).

Contrary to chemical pesticides, natural aromatic products are less harmful to humans and the environment. Essential oils are recognized as alternatives to chemical fumigants. They are isolated from non-woody plant material by steam or hydrodistillation. They are composed essentially of terpenoids, represented by monoterpenes $\left(C_{10}\right)$ and sesquiterpenes $\left(C_{15}\right)$ and a minority of aromatic phenols, oxides, ethers, alcohols, esters, aldehydes and ketones that can attribute to the aromatic profile of the plant. The chemicals in essential oil play a crucial function in plant defense against fungal and insecticidal attacks (6). Besides their use 
in food products as preservatives (7), antioxidants (8) and antimicrobials (9), essential oil can also be applied as repellent or insecticide for treatment of stored products $(10,11)$. These constitute effective ecofriendly alternatives to synthetic pesticides (10). They have been considered as pesticides and they have been used since 1947. At least 24 essential oil-based pesticides are registered in the United States (12). Botanicals are considered safe to humans due to their relatively high median lethal dose $\left(\mathrm{LD}_{50}\right)$ values to mammals so they have an important role in natural control strategies (13). The Artemisia genus is one of the most diversified among the Asteraceae family, which contains more than 500 species including a wide number of aromatic species (14) among which several species have an economic impact by their use in fragrance industry, medicine, food, forage, ornamentals or soil stabilizers (15). Our study focused on Artemisia species growing in Tunisia, especially on three species. The first is Artemisia herba-alba, which is the most commercially viable crop for industrial purposes in Tunisia. It constitutes $3 \%$ of the main essential oils destined for exportation (16). Moreover, it showed important antimicrobial and insecticidal effects $(17,18)$. The second species is Artemisia absinthium, which has been revealed to have several biological activities such as antimicrobial (19), acaricidal (20), insecticidal (18), anthelmintic, antiseptic, antispasmodic (21) and antioxidant (19). The third one is Artemisia campestris, showing several pharmacological activities such as antioxidant, antimicrobial and insecticidal (22).

In various studies essential oils have been extracted to screen their insecticidal activity without studying the relationship between the chemical composition and the relative activity. Moreover, few studies focused on the interactive effect of essential oils on their insecticidal activity.

In the present study, the insecticidal and repellent activities of A. absinthium, A. campestris and A. herba-alba essential oils are investigated against Tribolium castaneum in relation to chemical composition. Furthermore, the assessment of binary combinations of the essential oils was performed to detect their interactive effects against the tested insect.

\section{MATERIALS AND METHODS}

\section{Plant material and essential oil extraction}

In this study the upper part of Artemisia absinthium, A.campestris and $A$. herba-alba was used. These plants were collected from the region of Boughrara, Medenine, Tunisia $\left(33^{\circ} 32^{\prime} 16^{\prime \prime} \mathrm{N}\right.$ and $10^{\circ} 40^{\prime} 34^{\prime \prime} \mathrm{E}$ ) during February 2012 . Fresh shoots (200 g) were subjected to steam distillation by means of Clevenger apparatus (flask capacity 1000 mL, model TF-1000ml; TEFIC BIOTECH CO., Xi'an, PR China) with $400 \mathrm{~mL}$ of distilled water and boiled for 4 $\mathrm{h}$ at $100{ }^{\circ} \mathrm{C}$. The extracted oil was weighed and stored at $4{ }^{\circ} \mathrm{C}$ until used.

\section{GC-MS analysis of the essential oils}

The essential oils were analysed with HP 6890N gas chromatograph (GC; Agilent Technologies, Palo Alto, CA, USA) cou- pled with HP 5975B mass spectrometrer (MS; Agilent Technologies), equipped with a flame ionization detector and capillary column with HP-5 MS $5 \%$ phenylmethyl siloxane (30 m×0.25 $\mathrm{mm}$, film thickness $0.25 \mu \mathrm{m}$ ) under the following conditions: temperature program: $50^{\circ} \mathrm{C}$ for $2 \mathrm{~min}$ and raised at $7^{\circ} \mathrm{C} / \mathrm{min}$ to $250^{\circ} \mathrm{C}$, then held for $2 \mathrm{~min}$, injector temperature was $240^{\circ} \mathrm{C}$, the carrier gas was helium, with a flow rate of $1.2 \mathrm{~mL} / \mathrm{min}$, injected volume was $1 \mu \mathrm{L}$, with split mode at ratio of 1:50, transfer line temperature was $150^{\circ} \mathrm{C}$, and ion source temperature was $230^{\circ} \mathrm{C}$. Identification of the individual oil components was performed by comparison of retention times and mass spectral data with those of literature data $(23,24)$ and the Wiley 275 . L library $(25,26)$.

\section{Insect rearing}

T. castaneum adults were cultured on food medium composed of maize and wheat flour. The colony was reared in plastic jars at $26^{\circ} \mathrm{C}$ and $60 \%$ humidity in the dark. All experiments were carried out in a climate chamber under the same laboratory conditions.

\section{Bioassay of fumigant activity}

The fumigant effect of the three essential oils of Artemisia species and their combinations was evaluated against adults of T. castaneum. Whatman filter paper no. 1 circular discs (GE Healthcare Life Sciences, Little Chalfont, Buckinghamshire, UK) were cut to $3 \mathrm{~cm}$ and placed in the underside of the lid of a 40-mL glass vial, which contained a group of 10 insects. Paper discs attached to the inside top of the container lid were impregnated with different doses of essential oil $(25,50,100$ and $200 \mu \mathrm{L} / \mathrm{L}$ ) and vials were quickly closed. The fumigation test was carried out at $26^{\circ} \mathrm{C}$, with five replications. Percentage of mortality was determined $24 \mathrm{~h}$ after the treatment. The fumigation test was divided into two bioassays: the first one was performed at various volume fractions of the oils tested individually and the second one was used to evaluate the synergism/ antagonism among the three species of Artemisia. For this, different mixtures of essential oils were prepared in the same proportion, named $A B, A C, B C$ and $A B C$, where $A$ is the essential oil of $A$. absinthium, $B$ is the essential oil of $A$. campestris and $C$ the essential oil of $A$. herba-alba. The joint action of essential oil mixture was determined on the basis of probit analysis (27). The toxicity indices of different essential oils were lethal volume fractions causing 50 and $95 \%$ mortality of exposed insects $\left(\mathrm{LC}_{50}\right.$ and $\mathrm{LC}_{95}$ ). For the toxicity determination of essential oil mixtures, we used the synergistic ratio (SR) model (28):

$$
\mathrm{SR}=\mathrm{LC}_{50} \text { (essential oil alone)/LC } \text { (mixture) }
$$

where $S R$ is 1 for additive effect, $S R<1$ for antagonistic effect and $\mathrm{SR}>1$ for synergistic effect.

\section{Bioassay for repellency activity}

Repellency degrees of the phytochemicals against T. castaneum were evaluated using some modifications of the area preference method (29). Essential oils in different doses were applied on 9-cm Whatman filter paper no. 1 circular discs cut 
in half. Tested solutions were adjusted by a dilution of 1, 2, 4 and $8 \mu \mathrm{L}$ of each essential oil in $1 \mathrm{~mL}$ of acetone providing corresponding concentrations of $0.03,0.06,0.12$ and $0.25 \mu \mathrm{L} / \mathrm{cm}^{2}$. A volume of $0.5 \mathrm{~mL}$ of each essential oil solution was applied uniformly to a half filter paper and the second half was soaked with $0.5 \mathrm{~mL}$ of acetone using a micropipette (single-channel mechanical micropipette ( $1000 \mu \mathrm{L}$, model DG1120; Labomoderne, Paris, France). All filter papers and control were dried for $15 \mathrm{~min}$. Twenty unsexed adults aged seven days were placed at the centre of the filter paper disc and the number of insects on each half paper was counted after $2 \mathrm{~h}$ of exposure. Three replicates were set for each treatment. Percentage repellency (PR) after $2 \mathrm{~h}$ of exposure was calculated according to the formula:

$$
\mathrm{PR}=\left[\left(N_{\mathrm{c}}-N_{\mathrm{t}}\right) /\left(N_{\mathrm{c}}+N_{\mathrm{t}}\right)\right] \cdot 100
$$

where $N_{c}$ and $N_{t}$ were the number of insects in the negative control half and in the treated half, respectively.

\section{Statistical analysis}

Statistical analyses were conducted using SPSS software, v. 20.0 (30). Duncan's multirange test was used to assess the comparison between the mean values at $p<0.05$. The correction using Abbott's formula (31) was applied to correct mortality data for control response. Data from all replicates were used in probit analysis (27) to calculate $\mathrm{LC}_{50}$ and $\mathrm{LC}_{95}$. Principal component analysis (PCA) was applied to analyze the interdependence between Artemisia species and their chemical constituents.

\section{RESULTS AND DISCUSSION}

Our data indicate that essential oil yields varied within Artemisia species. The highest yield (in \%) was recorded in leaves of $A$. campestris $(0.31 \%)$ compared to that of $A$. herba-alba $(0.27$ $\%$ ) and A. absinthium (0.16\%); data not shown. In total, 48, 72 and 51 components were identified representing 100, 99.91 and $95.54 \%$ A. absinthium, A. campestris and A. herba-alba oil, respectively (Table 1 ). Common major compounds in all oils (in $\%)$ were: camphor 31.3, $\beta$-pinene 14.9, $\gamma$-terpinene 14.06 and germacrene 12.15, whereas the major components of $A$. absinthium essential oil (in \%) were: camphor 24.81, chamazulene 13.71, bornyl acetate 5.89 and myrcene 5.83; however, A. campestris essential oil was characterized by (in \%): $\beta$-pinene 14.49 , germacrene 7.15 and trans- $\beta$-ocimene 6.78 as major components. The dominant components detected in A. herba-alba essential oil were (in \%): $\beta$-thujone 12.5, a-thujone 8.78, sabinyl acetate 8.56 and terpinene-4-ol 8.51. The type and proportion of various monoterpenoids in the oil are characteristic of the genus and species. The composition of essential oils obtained from the tested Artemisia species in the current investigation showed a significant similarity to previous reports (32-37): the major component of the Tunisian A. absinthium was chamazulene, thujones are similar components from the essential oil of A. herba-alba and $\beta$-pinene was found in A. campestris collected from different geographic localities of Tunisia (33-35). Moreover, our results were in accordance with those of Riahi et al. (38) who found that the main components of $A$. absinthium in the semi-arid areas of Tunisia were camphor, chamazulene and bor-

Table 1. Identified volatile constituents of the essential oils of areal parts of Artemisia absinthium, A. campestris and A. herba-alba from Tunisia

\begin{tabular}{|c|c|c|c|c|c|}
\hline \multirow{2}{*}{ Compound } & \multirow{2}{*}{$\mathrm{RI}$} & \multicolumn{4}{|c|}{$w($ compound $) / \%$} \\
\hline & & A. absinthium (47) & A. campestris (67) & A. herba-alba (50) & Total \\
\hline \multicolumn{6}{|c|}{ Compounds whose total abundance is greater than 1} \\
\hline \multicolumn{6}{|c|}{ Acyclic monoterpenoids } \\
\hline Myrcene & 7.63 & 5.83 & 2.84 & 0.46 & 9.13 \\
\hline trans- $\beta$-Ocimene & 8.81 & - & 6.78 & - & 6.78 \\
\hline Linalool & 10.07 & 3.53 & - & - & 3.53 \\
\hline \multicolumn{6}{|c|}{ Bicyclic monoterpenoids } \\
\hline a-Pinene & 6.37 & 3.02 & 3.94 & 0.64 & 7.6 \\
\hline Sabinene & 7.24 & 0.27 & - & 1.03 & 1.3 \\
\hline trans-Sabinene hydrate & 9.37 & 1.52 & - & 0.41 & 1.93 \\
\hline Trimethylnaphtalene & 20.03 & 3.23 & - & - & 3.23 \\
\hline$\beta$-Pinene & 7.32 & 0.19 & 14.49 & 0.22 & 14.9 \\
\hline$\beta$-Thujone & 10.26 & - & 5.73 & 12.5 & 18.23 \\
\hline a-Thujone & 10.49 & - & 4.15 & 8.78 & 12.93 \\
\hline Camphor & 11.13 & 24.81 & 1.77 & 4.52 & 31.3 \\
\hline Borneol & 11.55 & 0.26 & 0.68 & 1.89 & 2.83 \\
\hline Bornyl acetate & 13.97 & 5.89 & 0.67 & 0.78 & 7.34 \\
\hline \multicolumn{6}{|c|}{ Bicycloheptanes } \\
\hline Camphene & 6.69 & 3.74 & 0.81 & 1.79 & 6.34 \\
\hline \multicolumn{6}{|c|}{ Cumenes } \\
\hline o-Cymene & 8.39 & 0.57 & 3.09 & 3.8 & 7.46 \\
\hline \multicolumn{6}{|c|}{ Cycloalkenes } \\
\hline Trimethyl-dihydrocyclopropainden-6(6a)-one & 20.64 & 3.12 & - & - & 3.12 \\
\hline \multicolumn{6}{|c|}{ Ketones } \\
\hline Chrysanthenone & 10.64 & - & 0.62 & 2.68 & 3.3 \\
\hline
\end{tabular}


Table 1. - continued

\begin{tabular}{|c|c|c|c|c|c|}
\hline \multirow{2}{*}{ Compound } & \multirow{2}{*}{$\mathrm{RI}$} & \multicolumn{4}{|c|}{$w($ compound $) / \%$} \\
\hline & & A. absinthium (47) & A. campestris (67) & A. herba-alba (50) & Total \\
\hline 2-Undecanone & 14.06 & 1.27 & - & - & 1.27 \\
\hline \multicolumn{6}{|c|}{ Menthane monoterpenoids } \\
\hline a-Terpinene & 8.2 & 2.09 & 0.89 & 3.35 & 6.33 \\
\hline Limonene & 8.48 & 1.16 & 5.56 & - & 6.72 \\
\hline$\gamma$-Terpinene & 9.15 & 3.59 & 5.65 & 4.82 & 14.06 \\
\hline a-Terpinolene & 9.81 & 0.67 & 0.72 & 1.43 & 2.82 \\
\hline p-Menth-2-en-1-ol & 10.58 & 0.27 & 0.31 & 1.49 & 2.07 \\
\hline 1-4-Terpineol & 11.78 & 4.97 & - & - & 4.97 \\
\hline Terpinene-4-ol & 11.90 & - & - & 8.51 & 8.51 \\
\hline a-Terpineol & 12.06 & 0.33 & 1.46 & 0.74 & 2.53 \\
\hline Sabinyl acetate & 14.15 & - & 2.33 & 8.56 & 10.89 \\
\hline \multicolumn{6}{|c|}{ Benzenoids } \\
\hline Dimethyl ethyl benzene & 13.5 & - & - & 3.93 & 3.93 \\
\hline \multicolumn{6}{|c|}{ Monocyclic monoterpenes } \\
\hline Piperitol & 12.30 & - & - & 1.11 & 1.11 \\
\hline \multicolumn{6}{|c|}{ Naphthalenes } \\
\hline Trimethyldihydronaphthalene & 18.25 & 1.03 & - & - & 1.03 \\
\hline Trimethylnaphtalene & 20.45 & 5.09 & - & - & 5.09 \\
\hline \multicolumn{6}{|c|}{ Oxanes } \\
\hline 1,8-Cineole & 8.55 & 0.31 & 2.24 & 5.45 & 8 \\
\hline \multicolumn{6}{|c|}{ Oxolanes } \\
\hline Davana ether & 17.79 & - & 0.45 & 2.09 & 2.54 \\
\hline cis-Davanone & 19.45 & - & - & 2.12 & 2.12 \\
\hline \multicolumn{6}{|c|}{ Sesquiterpenoids } \\
\hline Germacrene & 17.73 & 1.53 & 7.15 & 3.47 & 12.15 \\
\hline Bicyclogermacrene & 17.98 & - & 2.58 & 2.1 & 4.68 \\
\hline Spathulenol & 19.4 & - & 2.33 & - & 2.33 \\
\hline$\Delta$-Cadinene & 20.43 & - & 1.07 & - & 1.07 \\
\hline$\beta$-Eudesmol & 20.62 & - & 3.42 & - & 3.42 \\
\hline Chamazulene & 21.47 & 13.71 & - & - & 13.71 \\
\hline \multicolumn{6}{|c|}{ Compounds whose total abundance is less than 1} \\
\hline Terpinolene & 5.79 & - & 0.16 & 0.09 & 0.25 \\
\hline Tricyclene & 6.11 & 0.12 & 0.25 & 0.11 & 0.48 \\
\hline a-Thujene & 6.21 & 0.43 & 0.15 & 0.23 & 0.81 \\
\hline 6-Methyl-5-hepten-2-one & 7.55 & 0.23 & - & - & 0.23 \\
\hline a-Phellandrene & 7.93 & 0.45 & 0.09 & 0.19 & 0.73 \\
\hline 2-Nonanone & 9.87 & 0.53 & - & - & 0.53 \\
\hline Butanoic acid & 10.12 & 0.56 & - & - & 0.56 \\
\hline Filifolone & 10.16 & - & 0.33 & - & 0.33 \\
\hline 1,3,8-para-Menthatriene & 10.36 & - & - & 0.19 & 0.19 \\
\hline (e)-4,8-Dimethyl-1,3,7-nonatriene & 10.42 & - & 0.27 & - & 0.27 \\
\hline Cycloheptane,1,3,6-trimethylene & 10.86 & - & 0.1 & - & 0.1 \\
\hline a-Phellandrene epoxide & 10.98 & - & 0.61 & - & 0.61 \\
\hline$\gamma$-Terpinene & 10.98 & 0.18 & - & - & 0.18 \\
\hline Menthone & 11.26 & - & 0.08 & - & 0.08 \\
\hline trans-Chrysanthemal & 11.36 & - & - & 0.19 & 0.19 \\
\hline Pinocarvone & 11.46 & - & 0.21 & - & 0.21 \\
\hline 3-Nopinenone & 11.48 & - & - & 0.62 & 0.62 \\
\hline Myrcenol & 11.93 & 0.53 & - & - & 0.53 \\
\hline Myrtenal & 12.17 & - & 0.18 & - & 0.18 \\
\hline Verbenone & 12.46 & - & 0.13 & - & 0.13 \\
\hline Citronellol & 12.78 & - & 0.17 & - & 0.17 \\
\hline 2-Methylheptyl acetate & 12.9 & 0.8 & - & - & 0.8 \\
\hline Cuminaldehyde & 13.06 & - & 0.17 & - & 0.17 \\
\hline Citronellyl formate & 13.1 & - & 0.25 & - & 0.25 \\
\hline
\end{tabular}


Table 1. - continued

\begin{tabular}{|c|c|c|c|c|c|}
\hline \multirow{2}{*}{ Compound } & \multirow{2}{*}{ RI } & \multicolumn{4}{|c|}{$w($ compound $) / \%$} \\
\hline & & A. absinthium (47) & A. campestris (67) & A. herba-alba (50) & Total \\
\hline Chrystanthenyl acetate & 13.46 & - & 0.6 & - & 0.6 \\
\hline Perilla aldehyde & 13.77 & 0.17 & - & - & 0.17 \\
\hline Phenol,2-ethyl-4,5-dimethyl & 14.37 & - & - & 0.06 & 0.06 \\
\hline a-Coapene & 15.74 & - & 0.3 & - & 0.3 \\
\hline Nerylacetate & 15.78 & - & 0.22 & & 0.22 \\
\hline cis-Jasmone & 16.16 & - & - & 0.37 & 0.37 \\
\hline Methyl eugenol & 16.21 & 0.16 & - & - & 0.16 \\
\hline$\beta$-Caryophyllene & 16.58 & 0.71 & 0.74 & 0.48 & 1.93 \\
\hline a-Dodecylene & 16.65 & 0.2 & - & - & 0.2 \\
\hline trans- $\beta$-Fanesene & 17.14 & - & 0.17 & - & 0.17 \\
\hline a-Humulene & 17.2 & - & 0.18 & - & 0.18 \\
\hline Ethyl cinnamate & 17.37 & - & 0.26 & 0.52 & 0.78 \\
\hline a-Ylangene & 17.61 & - & 0.51 & - & 0.51 \\
\hline$(\mathrm{E}, \mathrm{E})$ - $\mathrm{a}$-Farnesene & 18.05 & - & 0.66 & - & 0.66 \\
\hline a-Amorphene & 18.26 & - & 0.34 & - & 0.34 \\
\hline Methylpatchenol & 18.95 & - & 0.18 & - & 0.18 \\
\hline Nerolidol & 19.03 & - & 0.51 & & 0.51 \\
\hline Farnesol & 19.03 & - & - & 0.28 & 0.28 \\
\hline Citronnellylpropanoate & 19.18 & - & 0.31 & - & 0.31 \\
\hline Caryophyllene oxide & 19.49 & 0.16 & - & - & 0.16 \\
\hline Alloaromadendrene & 19.5 & - & 0.92 & - & 0.92 \\
\hline (-)-Caryophullene oxide & 19.5 & - & - & 0.52 & 0.52 \\
\hline$\gamma$-Gurjunene & 19.66 & - & 0.41 & - & 0.41 \\
\hline Viridiflorol & 19.66 & - & - & 0.17 & 0.17 \\
\hline Geranyl isovalerate & 19.73 & 0.13 & 0.77 & - & 0.9 \\
\hline Bicyclo $(5,5,2)$ nonane-4,8,8-trimethyl-2-methylene & 19.95 & - & 0.5 & - & 0.5 \\
\hline$\beta$-Maaliene & 20.1 & - & 0.68 & - & 0.68 \\
\hline$\beta$-Myrcene & 20.14 & - & & 0.28 & 0.28 \\
\hline Diethyl-dimethyl-tricyclo-hexane & 20.19 & 0.27 & - & - & 0.27 \\
\hline$\beta$-Cadinene & 20.27 & - & 0.43 & - & 0.43 \\
\hline Isospathulenol & 20.38 & - & & 0.29 & 0.29 \\
\hline (2S,5E)-Caryophyll-5-en-12-al & 20.45 & 0.6 & - & - & 0.6 \\
\hline a-Amorphene & 20.5 & - & 0.39 & - & 0.39 \\
\hline 1,2-Dimethyl-4-methylene-3-phenyl-cyclopentene & 20.58 & 0.25 & - & - & 0.25 \\
\hline T-Muurolol & 20.65 & - & - & 0.4 & 0.4 \\
\hline Ethanone & 20.88 & - & - & 0.42 & 0.42 \\
\hline Calamenene & 21.17 & - & 0.67 & - & 0.67 \\
\hline Y-trans-aeaqui-Cyclocitral & 21.17 & - & - & 0.36 & 0.36 \\
\hline (8)Paracyclophane-2,4-diene & 21.18 & 0.51 & - & - & 0.51 \\
\hline Geranyl butyrate & 21.23 & - & 0.28 & - & 0.28 \\
\hline Mintsulfide & 22 & - & 0.17 & - & 0.17 \\
\hline N-Methylsuccinimide & 23.43 & - & 0.22 & - & 0.22 \\
\hline Palmiticacid & 25.09 & - & - & 0.34 & 0.34 \\
\hline 2,4-Dimethylfuran & 25.48 & 0.22 & - & - & 0.22 \\
\hline Bromoacetonitrile & 25.79 & 0.99 & - & - & 0.99 \\
\hline Phytol & 27.1 & - & 0.25 & 0.26 & 0.51 \\
\hline 2-Acetyl-4-(2,5-dichlorophenyl) furan & 30.13 & - & 0.17 & - & 0.17 \\
\hline
\end{tabular}

Number in the brackets next to the plant name indicates the total number of identified compounds in its oil, Rl=retention index

nyl acetate. To evaluate the chemotaxonomic significance of the essential oils of the three Artemisia species, a total number of 40 components whose total abundance is more than $1 \%$ were classified in 13 chemical families (Table 1), which were processed with PCA.
Among the 13 chemical families investigated from the three Artemisia species, the most abundant were bicyclic monoterpenes, followed by menthane monoterpenoids, sesquiterpenoids, acyclic monoterpenoids and the least abundant chemicals were monocyclic monoterpenoids (Fig. 1). 


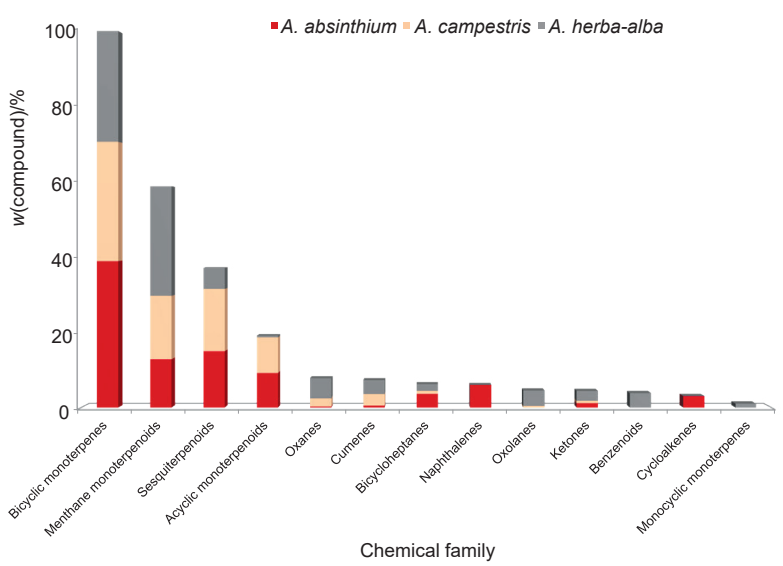

Fig. 1. Chemical families and relative contents of essential oils from Artemisia absinthium, A. campestris and A. herba-alba

It is important to note the absence of oxolanes, benzenoids and monocyclic monoterpenes from A. absinthium. Naphthalenes, benzenoids, cycloalkenes and monocyclic monoterpenes were not identified in A. campestris while A. herba-alba did not contain naphthalenes and cycloalkenes.

The results of PCA for Artemisia species are shown in Fig. 2. Based on this analysis, a higher variability within the essential oils of Artemisia species is observed. First PCA axis explained $75.8 \%$ of the total variance whereas the second axis revealed $24.1 \%$ of the total variance (Fig. 2). The first principal component separates bicyclic monoterpenes, sesquiterpenoids, acyclic monoterpenoids, naphthalenes, bicycloheptanes and cycloalkenes from menthane monoterpenoids, oxanes, oxolanes, cumenes, benzenoids, ketones and monocyclic monoterpenes. The second principal component distinguishes sesquiterpenoids, acyclic monoterpenoids, oxanes and cumenes from the other compounds.

Menthane monoterpenoids, oxanes, oxolanes, cumenes, benzenoids, ketones and monocyclic monoterpenes distinctly overlap in a separate group in the PCA, represented by $A$. herba-alba. The other groups overlap and are divided into two

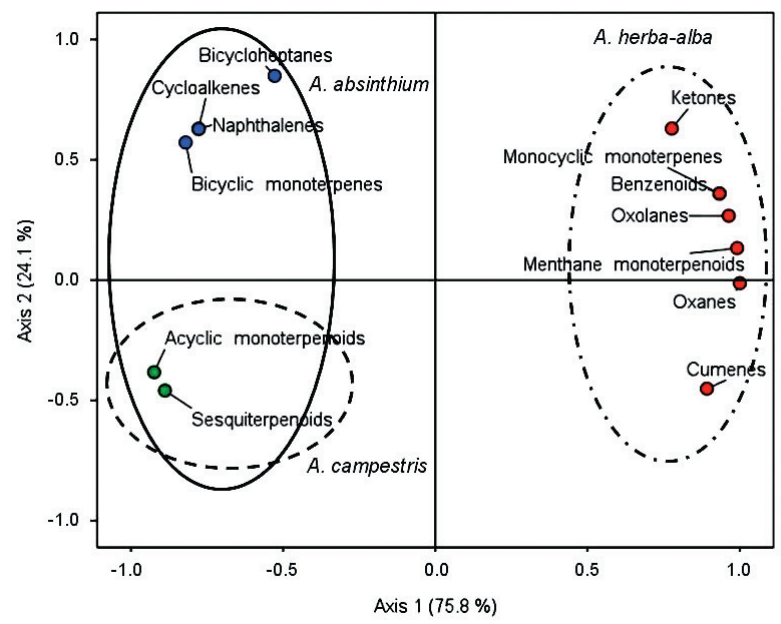

Fig. 2. Principal component analysis of 13 major chemical families in essential oils of three Artemisia species subgroups; the first one is represented by sesquiterpenoids and acyclic monoterpenoids, and is related to A. campestris. The second one is made of sesquiterpenoids, acyclic monoterpenoids, bicyclic monoterpenes, naphthalenes, bicycloheptanes and cycloalkenes, and is related to A. absinthium. These findings are in agreement with those cited by Dib et al. (39) indicating that $A$. campestris collected from four different localities in Southern Tunisia contains a high level of sesquiterpenes.

The results of fumigation bioassay are shown in Fig. 3. At the two lowest volume fractions, the three Artemisia sp. did not show statistical differences. At $100 \mu \mathrm{L} / \mathrm{L}$, essential oil from $A$. herba-alba was more toxic than the other two Artemisia sp. after $24 \mathrm{~h}$ of exposure. At the highest volume fraction $(200 \mathrm{LL} / \mathrm{L})$, all three Artemisia sp. reached the highest toxic effect. The fumigant toxicity test showed that $A$. herba-alba was more toxic than the other two Artemisia species. These results were confirmed by $\mathrm{LC}_{50}$ values shown in Table 2. In a fumigant test, a dosage of $142.8 \mu \mathrm{L} / \mathrm{L}$ of $A$. herba-alba was sufficient to kill 50 $\%$ of insects after $24 \mathrm{~h}$ of treatment, followed by $A$. absinthium and $A$. campestris with $\mathrm{LC}_{50}$ of 147.6 and $151.3 \mu \mathrm{L} / \mathrm{L}$ respectively. These results show clearly the effectiveness of $A$. herba-alba in comparison with the other two Artemisia species. In a previous study of Titouhi et al. (35) A. herba-alba exhibited the best insecticidal effect against the two stored grain insects, Callosobruchus maculatus and Bruchus rufimanus, with $\mathrm{LC}_{50}$ of 7.7 and $8.3 \mu \mathrm{L} / \mathrm{L}$, respectively.

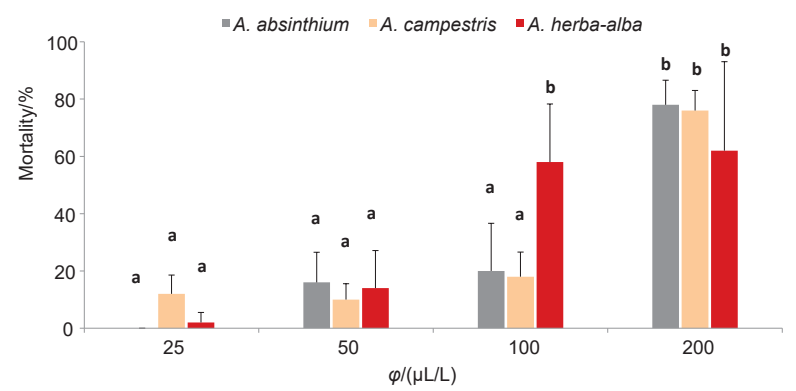

Fig. 3. Percentage of mortality of Tribolium castaneum after $24 \mathrm{~h}$ of exposure to various volume fractions of Artemisia absinthium, A. campestris and $A$. herba-alba essential oils

Table 2. Median lethal dose ( $\left(\mathrm{CC}_{50}\right)$ and $95 \%$ mortality $\left(\mathrm{LC}_{95}\right)$ values of fumigant bioassay with Artemisia absinthium, A. campestris and A. herba-alba essential oils after $24 \mathrm{~h}$

\begin{tabular}{|c|c|c|c|c|c|c|}
\hline Artemisia oil & $N$ & Slope \pm SE & $\frac{\mathrm{LC}_{50}}{\mu \mathrm{L} / \mathrm{L}}$ & $\frac{\mathrm{LC}_{95}}{\mu \mathrm{L} / \mathrm{L}}$ & $x^{2}$ & \\
\hline A. $a$ & 200 & & 147.6 & 262.7 & 13.67 & 2 \\
\hline A. car & 200 & $(0.14$ & 151.3 & 289.7 & 9.81 & 2 \\
\hline A. herba-alba & 200 & $(0.13 \pm 0.01)$ & 142.8 & 304.6 & 42.39 & 2 \\
\hline
\end{tabular}

$N=$ number of tested insects, $\mathrm{SE}=$ standard error of mean, $\mathrm{X}^{2}=$ Pearson chi-square value, $\mathrm{df}=$ degrees of freedom

Aromatic plants contain essential oils that are a complex mixture of acyclic and/or cyclic monoterpenoids used in perfume, cosmetic and pharmaceutical industries. Application of essential oils to manage insects and diseases in agriculture is the recently emerging trend (40). Monoterpenoids have a promising role in pest control due to their acute toxicity 
to insects and their repellent (41) and antifeedant potency (42). Moreover, among monoterpenes, ketones have higher insecticidal effect than alcohols or hydrocarbons (43-46) and even among ketones, toxicity may be of varying degrees $(47,48)$. The main cause of this variation may be due to either geographical or physicochemical characteristics (49). Numerous studies have shown the high toxicity of ketones against some stored pests like Sitophilus in fumigant and contact assays $(44,47,50)$. These results show that among the three $A r-$ temisia oils, the one from $A$. herba-alba has the best effect $\left(\mathrm{LC}_{50}=142.8 \mu \mathrm{L} / \mathrm{L}\right)$. Such finding suggests that the presence of ketone groups increases toxicity since $A$. herba-alba contains the highest mass fraction (58.64\%) of ketones (chrysanthenone and 2-undecanone). Other studies revealed insecticidal and repellent effect of terpenes on several stored grain pests, with a much more pronounced effect of ketone $(48,51)$. Moreover, A. herba-alba contains more menthane monoterpenoids, among them terpinen-4-ol, which was present only in this species. According to Chu et al. (52) terpinen-4-ol has insecticidal activity against Sitophilus zeamais (Motschulsky). Other researchers reported the effective contact toxicity of $A$. herba-alba against Tribolium castaneum (18).

In the interest of the improvement of the effectiveness of essential oil as pest management method, combined activities were examined to analyse interactions among the three essential oils. The joint effects of the three oils were assessed by mixtures adjusted at a ratio of 1:1 for binary mixtures and 1:1:1 for tertiary mixtures against Tribolium castaneum adults. In the present study, combinations of Artemisia essential oils exhibited lower insecticidal activity than single oils. The activity did not exceed $60 \%$ of mortality at the highest volume fraction $(200 \mu \mathrm{L} / \mathrm{L})$. Fig. 4 shows that there are no statistical differences among the four combinations tested at four volume fractions, although the toxic effect of all the tested combinations at the highest volume fraction was relatively higher.

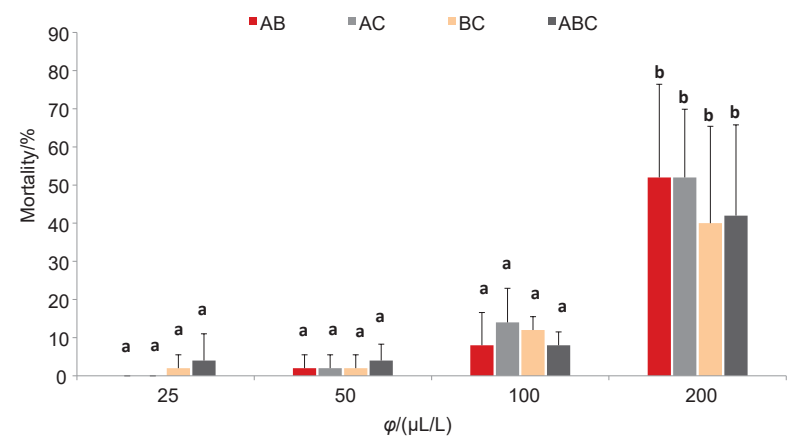

Fig. 4. Percentage of mortality of Tribolium castaneum exposed to various volume fractions of combinations of Artemisia absinthium (A), A. campestris (B) and A. herba-alba (C) essential oils after $24 \mathrm{~h}$ of exposure

The synergistic ratio (SR) shows antagonistic effects of all mixtures (Table 3), which indicates that oils tested alone have the most toxic effect. It has been known that mixtures of compounds increase the insecticidal effect, because insect sensitivity differs from one compound to another (53). In our
Table 3. Synergistic ratio (SR) of three combined Artemisia sp. essential oils against Tribolium castaneum adults after $24 \mathrm{~h}$ of exposure

\begin{tabular}{|c|c|c|c|c|}
\hline Artemisia oil & $\begin{array}{l}\text { Combined } \\
\text { oils }\end{array}$ & $\begin{array}{l}\text { Combined } \\
\mathrm{LC}_{50} /(\mu \mathrm{L} / \mathrm{L})\end{array}$ & $\begin{array}{c}\text { Synergistic } \\
\text { ratio (SR) }\end{array}$ & Effect \\
\hline $\begin{array}{l}\text { A. absinthium } \\
\text { (A) }\end{array}$ & $\begin{array}{c}A \\
A+B \\
A+C \\
A+B+C\end{array}$ & & 0.66 & $\begin{array}{l}\text { Antagonism } \\
\text { Antagonism } \\
\text { Antagonism }\end{array}$ \\
\hline $\begin{array}{l}\text { A. campestris } \\
\text { (B) }\end{array}$ & $\begin{array}{c}B \\
B+A \\
B+C \\
B+A+C\end{array}$ & & $\begin{array}{l}0.77 \\
0.68 \\
0.68\end{array}$ & $\begin{array}{l}\text { Antagonism } \\
\text { Antagonism } \\
\text { Antagonism }\end{array}$ \\
\hline $\begin{array}{l}\text { A. herba-alba } \\
\text { (C) }\end{array}$ & $\begin{array}{c}C \\
C+A \\
C+B \\
C+A+B\end{array}$ & $\begin{array}{l}142.8 \\
192.4 \\
221.8 \\
221.3\end{array}$ & $\begin{array}{l}0.74 \\
0.64 \\
0.64\end{array}$ & $\begin{array}{l}\text { Antagonism } \\
\text { Antagonism } \\
\text { Antagonism }\end{array}$ \\
\hline
\end{tabular}

$\mathrm{LC}_{50}=$ median lethal dose

study, the combination of the three essential oils had antagonist effect, showing that the combined application led to the decrease in insecticidal activity. In agreement with our results, Benelli et al. (54) showed antagonistic insecticidal activity of binary mixtures of Satureja montana and Pinus nigra essential oils against Culex quinquefasciatus. These findings show the importance of testing combined effects of essential oils used as control tools against pests, because positive or negative interactions between major components of the essential oil (alcoholic, phenolic, terpenic or ketonic compounds), minor components and biological activities can occur.

The results of the repellency test of the essential oils from three Artemisia species against Tribolium castaneum are shown in Table 4. It was found that the three samples exhibited obvious repellent activity towards T. castaneum. There were significant differences in repellency among the tested oils ( $p<0.05)$. Both A. absinthium and A. herba-alba oils provided $\geq 80 \%$ protection for $1 \mathrm{~h}$ against $T$. castaneum at 0.08 $\mu \mathrm{L} / \mathrm{cm}^{2}$. After $2 \mathrm{~h}$ of exposure, A. absinthium and A. campestris oils showed the highest repellent activity against $T$. castaneum adults at the same dose. Among the three essential oils, A. absinthium repelled rapidly and strongly at all tested exposure times, while $A$. herba-alba showed highest repellency by the first hour and its effect declined with prolonged exposure time. Contrary, A. campestris exerted its highest effect by the second hour of exposure. A. absinthium also showed quite promising insecticidal activity with $\mathrm{LC}_{95}$ of $262.7 \mu \mathrm{L} / \mathrm{L}$. In terms of repellency, it exhibited the highest effect at $0.08 \mu \mathrm{L} / \mathrm{cm}^{2}$ after 1 and $2 \mathrm{~h}$ of exposure. The chemical analysis shows that this species contains more bicyclic monoterpenes, bicycloheptanes, cycloalkenes and naphthalenes than the two other Artemisia sp. The above data show that fumigant and repellent activities of $A$. campestris are the weakest. The results of the repellency bioassay are in agreement with those reported by Jemâa (55) in that a higher repellency was recorded with $A$. absinthium essential oil than with $A$. herba-alba against both stored insects, T. castaneum and Oryzaephilus surinamensis. Moreover, previous study has demonstrated the repellent activity of A. absinthium oil against Phthorimaea operculella (56). Lower or higher amounts of bioactive ingredients in essential 
Table 4. Repellent activity of Artemisia absinthium, A. campestris and A. herba-alba essential oils on Tribolium castaneum adults after different exposure times using the filter paper test

\begin{tabular}{|c|c|c|c|c|}
\hline \multirow{2}{*}{$t($ exposure)/h } & \multirow{2}{*}{ Dose $/\left(\mu \mathrm{L} / \mathrm{cm}^{2}\right)$} & \multicolumn{3}{|c|}{ Repellent activity/\% } \\
\hline & & A. absinthium & A. campestris & A. herba-alba \\
\hline \multirow{5}{*}{1} & 0.01 & $(36.6 \pm 3.3)^{\mathrm{abc}}$ & $(56.6 \pm 8.8)^{\mathrm{abc}}$ & $(20.0 \pm 15.2)^{\mathrm{ab}}$ \\
\hline & 0.02 & $(63.3 \pm 6.6)^{\mathrm{bc}}$ & $(43.3 \pm 27.2)^{\mathrm{abc}}$ & $(43.3 \pm 8.8)^{\mathrm{abc}}$ \\
\hline & 0.04 & $(83.3 \pm 6.6)^{c}$ & $(76.3 \pm 14.4)^{\mathrm{bc}}$ & $(70.0 \pm 11.5)^{b c}$ \\
\hline & 0.08 & $(90.0 \pm 5.7)^{c}$ & $(70.0 \pm 5.7)^{\mathrm{bc}}$ & $(80.0 \pm 5.7)^{c}$ \\
\hline & 0.01 & $(40.0 \pm 5.7)^{\mathrm{abc}}$ & $(76.6 \pm 3.3)^{b c}$ & $(6.66 \pm 18.5)^{a}$ \\
\hline \multirow{3}{*}{2} & 0.02 & $(56.6 \pm 12)^{\mathrm{abc}}$ & $(60.0 \pm 11.5)^{\mathrm{bc}}$ & $(40.0 \pm 5.7)^{\mathrm{abc}}$ \\
\hline & 0.04 & $(60.0 \pm 5.7)^{\mathrm{bc}}$ & $(73.3 \pm 14.5)^{\mathrm{bc}}$ & $(73.3 \pm 6.6)^{b c}$ \\
\hline & 0.08 & $(90.0 \pm 5.7)^{c}$ & $(83.3 \pm 8.8)^{c}$ & $(63.3 \pm 12.0)^{b c}$ \\
\hline
\end{tabular}

Data are presented as mean value \pm standard deviation, mean values with different letters in superscript are statistically different $(p<0.05)$

oil may be responsible for reducing the insect repellency and toxicity. In this context, our study shows that $A$. campestris essential oil is richer in sesquiterpenoids than the other two Artemisia species.

\section{CONCLUSION}

Artemisia essential oils showed promising effect in protecting the stored grains from Tribolium castaneum attacks. However, the effect varied significantly depending on species and chemical composition of each oil. In general, the strong insecticidal activity of $A$. herba-alba was associated with a high content of menthane monoterpenoids, whereas A. absinthium exhibited the highest repellent activity, based on its richness of bicyclic monoterpenes. Moreover, we observed that the combination of essential oils did not improve their insecticidal effect. Consequently, chemical composition affects the effectiveness of the desired essential oil or their mixtures. The above findings suggest that $A$. absinthium and A. herba-alba oils have a potential to be used separately as alternatives to chemical fumigants in the protection of stored cereals. A. herba-alba causes mortality of more than $60 \%$ of insect population at volume fraction of $200 \mu \mathrm{L} / \mathrm{L}$ within $24 \mathrm{~h}$ and A. absinthium repel $90 \%$ of insects at the dose of $0.08 \mu \mathrm{L} /$ $\mathrm{cm}^{2}$ after $2 \mathrm{~h}$ of exposure. The oils from these plant species may have an interesting potential as natural repellents and insecticides considering their noticeable effects at low applied volume fractions and short times of exposure. However, the evaluation of these activities under industrial conditions is mandatory to prove their practicable application.

\section{REFERENCES}

1. Haque MA, Nakakita H, Ikenaga H, Sota N. Development-inhibiting activity of some tropical plants against Sitophilus zeamais Motschulsky (Coleoptera: Curculionidae). J Stored Prod Res. 2000;36(3):281-7. https://doi.org/10.1016/S0022-474X(99)00048-X

2. Yildirim E, Ozbek H, Aslan I. Pests of stored products. Erzurum, Turkey: Ataturk University Agricultural Faculty Press No. 191; 2001. p. 117.
3. Bond EJ. Manual of fumigation for insect control. Rome, Italy: Food and Agricultural Organization of the United Nations; 1984. pp. 298-306. Available from: http://www.fao. org/docrep/X5042E/x5042E00.htm.

4. Fields PG, White NDG. Alternatives to methyl bromide treatments for stored-product and quarantine insects. Annu Rev Entomol. 2002;47:331-59.

https://doi.org/10.1146/annurev.ento.47.091201.145217

5. Van Someren Graven JE. Guide to fumigation under gasproof sheets. Rome, Italy: Food and Agricultural Organization of the United Nations; 2004. Available from: www.fao. org/3/a-AU098e.pdf.

6. Langenheim JH. Higher plant terpenoids: A phytocentric overview of their ecological roles. J Chem Ecol. 1994;20(6):1223-80. https://doi.org/10.1007/BF02059809

7. Kovač J, Gavarić N, Bucar F, Smole Možina S. Antimicrobial and resistance modulatory activity of Alpinia katsumadai seed extract, essential oil and post-distillation extract. Food Technol Biotechnol. 2014;52(2):248-54.

8. Tural S, Turhan S. Properties and antioxidant capacity of anchovy (Engraulis encrasicholus) by-product protein films containing thyme essential oil. Food Technol Biotechnol. 2017;55(1):77-85.

https://doi.org/10.17113/ftb.55.01.17.4824

9. Pilevar Z, Hosseini H, Hajimehdipoor H, Shahraz F, Alizadeh L, Mousavi Khaneghah A, Mahmoudzadeh M. The anti-Staphylococcus aureus effect of combined Echinophora platyloba essential oil and liquid smoke in beef. Food Technol Biotechnol. 2017;55(1):117-24. https://doi.org/10.17113/ftb.55.01.17.4633

10. Isman MB, Machial CM. Pesticides based on plant essential oils: From traditional practice to commercialization. In: Rai M, Carpinella MC, editors. Naturally occurring bioactive compounds. Amsterdam, the Netherlands: Elsevier B.V.; 2006. pp. 29-44.

11. Bakkali F, Averbeck S, Averbeck D, Idaomar M. Biological effects of essential oils - A review. Food Chem Toxicol. 2008;46(2):446-75.

https://doi.org/10.1016/j.fct.2007.09.106 
12. The strategy of integrated mite management. In: Hoy MA, editor. Agricultural Acarology: Introduction to Integrated Mite Management. Boca Raton, FL, USA: CRC, Taylor \& Francis Group; 2011. p. 61.

13. Regnault-Roger C. Essential oils in insect control. In: Ramawat KG, Mérillon JM, editors. Natural products. Berlin, Germany: Springer-Verlag; 2013. pp. 4087-102.

https://doi.org/10.1007/978-3-642-22144-6_181

14. Pellicer J, Garnatje T, Vallès J. Artemisia (Asteraceae): Understanding its evolution using cytogenetic and molecular systematic tools, with emphasis on subgenus Dracunculus. In: Muñoz-Torrero D, editor. Recent advances in pharmaceutical sciences. Trivandrum, Kerala, India:Transworld Research Network; 2011. pp. 199-222.

15. Vallès J, Torrell M, Garnatje T, Garcia-Jacas N, Vilatersana R, Susanna A. The genus Artemisia and its allies: Phylogeny of the subtribe Artemisiinae (Asteraceae, Anthemideae) based on nucleotide sequences of nuclear ribosomal DNA internal transcribed spacers (ITS). Plant Biol. 2003;5(3):274-84. https://doi.org/10.1055/s-2003-40790

16. Cultivation of aromatic and medicinal plants. Tunis, Tunisia: Agricultural Investment Promotion Agency (APIA); 2003. pp. 120-32.

17. Mighri $H$, Hajlaoui $H$, Akrout A, Najjaa H, Neffati M. Antimicrobial and antioxidant activities of Artemisia herba-alba essential oil cultivated in Tunisian arid zone. C R Chim. 2010;13(3):380-6.

https://doi.org/10.1016/j.crci.2009.09.008

18. Bachrouch O, Ferjani N, Haouel S, Mediouni BenJemâa J. Major compounds and insecticidal activities of two Tunisian Artemisia essential oils toward two major coleopteran pests. Ind Crops Prod. 2015;65:127-33.

https://doi.org/10.1016/j.indcrop.2014.12.007

19. Lopes-Lutz D, Alviano DS, Alviano CS, Kolodziejczyk PP. Screening of chemical composition, antimicrobial and antioxidant activities of Artemisia essential oils. Phytochemistry. 2008;69(8):1732-8.

https://doi.org/10.1016/j.phytochem.2008.02.014

20. Chiasson $H$, Bélanger $A$, Bostanian $N$, Vincent $C$, Poliquin $A$. Acaricidal properties of Artemisia absinthium and Tanacetum vulgare (Asteraceae) essential oils obtained by three methods of extraction. J Econ Entomol. 2001;94(1):167-71. https://doi.org/10.1603/0022-0493-94.1.167

21. Joshi RK. Volatile composition and antimicrobial activity of the essential oil of Artemisia absinthium growing in Western Ghats region of North West Karnataka, India. Pharm Biol. 2013;51(7):888-92. https://doi.org/10.3109/13880209.2013.768676

22. AI-Snafi AE. The pharmacological importance of Artemisia campestris - A review. Asian J Pharm Res. 2015;5(2):88-92.

23. Kováts E. Characterization of organic compounds by gas chromatography. Part 1: Retention indices of aliphatic halides, alcohols, aldehydes and ketones. Helv Chim Acta.1958;41(7):1915-32.

https://doi.org/10.1002/hlca.19580410703
24. Shibamoto T. Retention indices in essential oil analysis. In: Sandra P, Bicchi C, editors. Capillary gas chromatography in essential oil analysis. Heidelberg, Germany: Hüthig; 1987. pp. 259-74.

25. Adams R. Identification of essential oils by ion trap mass spectroscopy. San Diego, CA, USA: Academic Press, Inc.; 1989.

26. McLafferty FW, Stauffer DB, editors. Wiley/NBS registry of mass spectral data, volumes 1-7. New York, NY, USA: John Wiley and Sons; 1989.

27. Finney DJ. Probit analysis. New York, NY, USA: Cambridge University Press; 1971. p. 318.

28. Hewlett PS, Plackett RL. A unified theory for quantal responses to mixtures of drugs: Non-interactive action. Biometrics. 1959;15(4):591-610. https://doi.org/10.2307/2527657

29. McDonald LL, Guy RH, Speirs RD. Preliminary evaluation of new candidate materials as toxicants, repellents, and attractants against stored-product insects. In: USDA Marketing Research Report No. 882. Whashington, DC, USA: Agricultural Research Service, US Department of Agriculture; 1970.

30. Ho R, editor. Handbook of univariate and multivariate data analysis with IBM SPSS. Boca Raton, FL, USA: Chapman and Hall/CRC, Taylor \& Francis Group; 2014.

31. AbbottWS. A method of computing the effectiveness of an insecticide. J Econ Entomol. 1925;18(2):265-7.

https://doi.org/10.1093/jee/18.2.265a

32. Msaada K, Salem N, Bachrouch O, Bousselmi S, Tammar S, Alfaify $\mathrm{A}$, et al. Chemical composition and antioxidant and antimicrobial activities of wormwood (Artemisia absinthium L.) essential oils and phenolics. J Chem. 2015;Article ID 804658.

https://doi.org/10.1155/2015/804658

33. Haouari M, Ferchichi A. Essential oil composition of Artemisia herba-alba from Southern Tunisia. Molecules. 2009;14(4):1585-94.

https://doi.org/10.3390/molecules14041585

34. Neffati A, Skandrani I, BenSghaier M, Bouhlel I, Kilani S, Ghedira K, et al. Chemical composition, mutagenic and antimutagenic activities of essential oils from (Tunisian) Artemisia campestris and Artemisia herba-alba. J Essent Oil Res. 2008;20(5):471-7. https://doi.org/10.1080/10412905.2008.9700061

35. Titouhi F, Amri M, Messaoud C, Haouel S, Youssfi S, Cherif A, Ben Jemâa JM. Protective effects of three Artemisia essential oils against Callosobruchus maculatus and Bruchus rufimanus (Coleoptera: Chrysomelidae) and the extended side-effects on their natural enemies. J Stored Prod Res. 2017;72:11-20.

https://doi.org/10.1016/j.jspr.2017.02.007

36. Younsi F, Trimech R, Boulila A, Ezzine O, Dhahri S, Boussaid M, Messaoud C. Essential oil and phenolic compounds of Artemisia herba-alba (Asso.): Composition, antioxidant, 
antiacetylcholinesterase, and antibacterial activities. Int J Food Prop. 2016;19(7):1425-38.

https://doi.org/10.1080/10942912.2015.1079789

37. Bellili S, Jazi S, Hrira MY, Lamari A, Dhifi W, Diouani MF, et al. Phytochemical identification of volatile fraction, essential oil and screening of antioxidant, antibacterial, allelopathic and insecticidal potential from Artemisia herba-alba leaves. Main Group Chem. 2017;16(2):95-109. https://doi.org/10.3233/MGC-170229

38. Riahi L, Chograni H, Elferchichi M, Zaouali Y, Zoghlami N, Mliki A. Variations in Tunisian wormwood essential oil profiles and phenolic contents between leaves and flowers and their effects on antioxidant activities. Ind Crops Prod. 2013;46:290-6.

https://doi.org/10.1016/j.indcrop.2013.01.036

39. Dib I, Angenot L, Mihamou A, Ziyyat A, Tits M. Artemisia campestris L.: Ethnomedicinal, phytochemical and pharmacological review. J Herb Med. 2017;7:1-10. https://doi.org/10.1016/j.hermed.2016.10.005

40. Singh G. Pest control through essential oil. In: Handa SS, Kaul MK, editors. Supplement to cultivation and utilization of aromatic plants. Regional Research Laboratory, Jammu-Tawi. Jammu-Tawi, India: Council of Scientific and Industrial Research, Jammu-Tawi; 1997. pp. 49-62.

41. Watanabe K, Shono Y, Kakimizu A, Okada A, Matsuo N, Satoh A, Nishimura H. New mosquito repellent from Eucalyptus camaldulensis. J Agric Food Chem. 1993;41(11):2164-6. https://doi.org/10.1021/jf00035a065

42. Hough-Goldstein JA. Antifeedant effects of common herbs on the Colorado potato beetle (Coleoptera: Chrysomelidae). Environ Entomol. 1990;19(2):234-8.

https://doi.org/10.1093/ee/19.2.234

43. Abdelgaleil SAM, Mohamed MIE, Badawy MEI, El-Arami SAA. Fumigant and contact toxicities of monoterpenes to Sitophilus oryzae (L.) and Tribolium castaneum (Herbst) and their inhibitory effects on acetylcholinesterase activity. J Chem Ecol. 2009;35(5):518-25. https://doi.org/10.1007/s10886-009-9635-3

44. Lee SE, Peterson CJ, Coats JR. Fumigation toxicity of monoterpenoids to several stored product insects. J Stored Prod Res. 2003;39(1):77-85.

https://doi.org/10.1016/S0022-474X(02)00020-6

45. Chaubey MK. Fumigant toxicity of essential oils and pure compounds against Sitophilus oryzae L. (Coleoptera: Curculionidae). Biol Agric Hortic. 2012;28(2):111-9. https://doi.org/10.1080/01448765.2012.681352

46. Yildirim E, Emsen B, Kordali S. Insecticidal effects of monoterpenes on Sitophilus zeamais Motschulsky (Coleoptera: Curculionidae). J Appl Bot Food Qual. 2013;86:198-204. https://doi.org/10.5073/JABFQ.2013.086.027
47. Germinara G, De Cristofaro A, Rotundo G. Bioactivity of short-chain aliphatic ketones against adults of the granary weevil, Sitophilus granarius (L.). Pest Manag Sci. 2012;68(3):371-7.

https://doi.org/10.1002/ps.2272

48. Herrera JM, Zunino MP, Dambolena JS, Pizzolitto RP, Gañan NA, Lucini El, Zygadlo JA. Terpene ketones as natural insecticides against Sitophilus zeamais. Ind Crops Prod. 2015;70:435-42.

https://doi.org/10.1016/j.indcrop.2015.03.074

49. Grodnitzky JA, Coats JR. QSAR evaluation of monoterpenoids' insecticidal activity. J Agric Food Chem. 2002;50(16):4576-80.

https://doi.org/10.1021/jf0201475

50. Tripathi AK, Prajapati V, Kumar S. Bioactivity of L-carvone, D-carvone and dihydrocarvone towards three stored product beetles. J Econ Entomol. 2003;96(5):1594-601.

https://doi.org/10.1093/jee/96.5.1594

51. Herrera JM, Zunino MP, Massuh Y, Pizzollito RP, Dambolena JS, Gañan NA, Zygadlo JA. Fumigant toxicity from five essential oils rich in ketones against Sitophilus zeamais (Motschulsky). Agriscientia. 2014;31(1):35-41.

52. Chu SS, Liu ZL, Du SS, Deng ZW. Chemical composition and insecticidal activity against Sitophilus zeamais of the essential oils derived from Artemisia giraldii and Artemisia subdigitata. Molecules. 2012;17(6):7255-65.

https://doi.org/10.3390/molecules17067255

53. Singh R, Koul O, Rup PJ, Jindal J. Toxicity of some essential oil constituents and their binary mixtures against Chilo partellus (Lepidoptera: Pyralidae). Int J Trop Insect Sci. 2009;29(2):93-101.

https://doi.org/10.1017/S1742758409990087

54. Benelli G, Pavela R, Canale A, Cianfaglione K, Ciaschetti G, Conti F, et al. Acute larvicidal toxicity of five essential oils (Pinus nigra, Hyssopus officinalis, Satureja montana, Aloysia citrodora and Pelargonium graveolens) against the filariasis vector Culex quinquefasciatus: Synergistic and antagonistic effects. Parasitol Int. 2017;66(2):166-71.

https://doi.org/10.1016/j.parint.2017.01.012

55. Jemâa JMB. Essential oil as a source of bioactive constituents for the control of insect pests of economic importance in Tunisia. Med Aromat Plants. 2014;3(2):158.

https://doi.org/10.4172/2167-0412.1000158

56. Naghizadeh S, Rafiee-Dastjerdi H, Golizadeh A, Esmaielpour $B$, Mahdavi V. The effects of essential oils of Artemisia absinthium L., Achillea millefolium L. and Artemisia dracunculus L. against potato tuber moth, Phthorimaea operculella Zeller (Lepidoptera: Gelechiidae). JJAS. 2016;12(4):1115-23. https://doi.org/10.12816/0035072 